\title{
Food Production in Indo-Gangetic Plains: To Understand the Role of Water and Hydrology
}

\author{
Singh Alka, Satarupa Chakravarty, M. Rajeshwor, Nilabja Ghosh ${ }^{*}$ \\ Institute of Economic Growth, Delhi University Enclave, Delhi, India.
}

\begin{abstract}
How to cite this paper: Singh Alka, Satarupa Chakravarty, M. Rajeshwor, Nilabja Ghosh. (2020) Food Production in Indo-Gangetic Plains: To Understand the Role of Water and Hydrology. International Journal of the Science of Food and Agriculture, 4(4), 413-426.

DOI: $10.26855 /$ ijfsa.2020.12.008
\end{abstract}

Received: September 17, 2020

Accepted: October 16, 2020

Published: November 20, 2020

*Corresponding author: Nilabja Ghosh, Institute of Economic Growth, Delhi University Enclave, Delhi, India.

Email: nila@iegindia.org

\begin{abstract}
This paper attempts to understand the production dynamics of food crop rice in six states of the Indo-Gangetic Plains in India with data analysis, bringing together both economic and climatic factors and emphasizing water as an input that naturally and strategically links regions. A model is built and estimated, taking care of econometric issues and embedding causality relations that are based on both theory and empirical evidences. The crop, despite being a major staple, competes for land with other food and cash crops in the market and its yield is sensitive to inputs prices. Moving beyond the economic rationality behind decisions, the theorization accounts for spatio-temporal inter-relations of water as suggested by geo-structural information. It is clear from the results that both acreage and yield of rice are deeply related to geography and interventions that determine the quality of water access, but the effect of rainfall is temporally and spatially varied and dispersed. Direction of rivers, existence of dams and reservoirs and quality of water management decide the location, timing and role of rainfall that determines production. While influential locations are hydrologically linked regions that can be proximate or distant, both current rainfall and past rainfall may be important. The rainfall-production relations could be explained by not only known pathways of surface water flows but probably also by integration of ground water below the surface, water allocation among states and sharing of hydroelectric power generated from water stored in common reservoirs. Limited knowledge about nature, inadequate access to information on the extents of aquifers, spatial interconnectedness among weather and paucity of trans-boundary data are limitations to the study but the model itself is dynamic and needs to track the acquisition of knowledge and data, transitions of water management tendencies revealed by climate change and planned linkages of basins.
\end{abstract}

\section{Keywords}

River basin, water management, agriculture, supply response, climate change, dams, reservoir

\section{Introduction}

Food production in the Indo-Gangetic Plains (IGP) of India has been critical in shaping India's development outlook. Concerns over soil and water use efficiency, a shift of attention towards the eastern plains and diversification from cereal crops [1, 2, 3] underline the current transitions in the agricultural policy for IGP. The large number of crops grown, though varied in their agronomic demands, competes for scarce land, water and financial resources. Water is a natural resource, competing demands for which arise in many other sectors too. Human control on its supply to any place is limited but possible. While in some crop cases abundant water is an advantage, excess moisture is damaging for others 
but rainfall at certain stages of growth can benefit or hurt any crop.

While markets reflecting changes in consumer tastes and the force of globalization influence the choice of crops, to assure reasonable farm income, the government intervenes by tinkering with minimum support prices (MSP) and expanding state procurement operations [4]. Government invests on irrigation [5] to redistribute and optimize the use of limited water resource among geographically diverse areas. Climate change will present new challenges and demand suitable responses from water planners, necessitating a full understanding of India's water economy and how best it can adapt to the hydro-climatic changes. Monitoring food and water is gaining primacy for avoiding disasters.

Historically, water has been a major constraint for Indian agriculture. Profoundly inter-related, surface and sub-surface flows of water are defined by not only monsoon performances but also the geographical properties of heterogeneous topographies. Interventions with dams and barrages ${ }^{1}$, made on the natural hydrology, amend water's availability, directions of flow and its distribution. River Basin is the government's basic hydrological unit for developing water resources [6] by intervention. The IGP stands out as a composite unit of main and minor basins of rivers Ganga, Indus, Yamuna and Brahmaputra all of which traverse mountain terrains and flow through multiple states. Shaped primarily by gradients, withits rivers, tributaries and sub-tributaries transcending sub-national and national borders, the entire basin, has a large trans-boundary dimension.

India is a regular victim of floods [7, 8], concentrated around northern Gangetic tributaries and in the Brahmaputra basin. Shortage of water is also a cause of agrarian distress and conflicts in IGP. Disputes arise over interventions within the country's border and beyond. Dependency between upstream and down-stream regions and the nexus between water, agriculture and power make meeting food security in south Asia challenging [9, 10]. Existing institutions for water management are found to be inadequate [11].

\section{Objective}

In the face of volatile markets, climate change, environmental risks and technological options, having a firm control over food production and farmers' welfare is important for national and international food security [12]. Many countries are monitoring farm production and outlook with an integrated use of tools like satellite imageries, telecommunication technologies, field insights and data analysis $[13,14,15,16]$. Data analysis in economics has for decades served in understanding causality of behavioural events and designing rational strategies. The potential gains from analyzing data on cross-discipline aspects for managing water and food production remain untapped. For a large country striving for development while grappling with food, water and energy security, planning and visualization would depend on a basic conceptualization of the production dynamics in an integrated framework.

This paper attempts to understand the production dynamics of food crop rice with data analysis, bringing together both economic and climatic factors, emphasizing water as an input that naturally and strategically links regions. Production is studied for six major growing states across IGP, namely, Punjab, Haryana, Uttar Pradesh, West Bengal, Bihar and Assam. A modeling approach is adopted, taking care of econometric issues and embedding causality relations that are intuitive or theory-based as well as empirical or evidence-based. Moving beyond the economic rationality behind decisions, the theorization accounts for spatio-temporal inter-relations of water as suggested by geo-structural information. Assessed for its performance, the selected model is analyzed further to identify the factors that determine rice production and appraise how multi-dimensional rainfall distribution impacts on production. After the introduction and the statement of objectives (2), an account is given of river linkages of northern India (section 3) followed by the method of analysis (4), its findings with a discussion of the results (5) and a conclusion (6).

\section{Background of India's Agriculture and Waterscape}

Sprawled across 140 million hectares of net sown area, 36 distinct climatic regions and heterogeneous terrains, Indian agriculture is diversified among food and cash crops presenting a competition for land and resources. Some of the IGP states accommodate more than one meteorological subdivision (MET) each of which represents climatic near-homogeneity. Irrigation requires surface or ground water via canals, rivers, tanks, wells and other equipment that operates with electric power that in turn can be produced from stored water and shared among states (Figure 2). Thus, water for farming comes from not only rainfall in the METs within the study state but also from systems that bring water and electricity from rainfall in METs located outside.

\subsection{Crops}

Kharif or monsoon rice is most widely grown and consumed in the country but thrives best in water-rich, humid, warm and fertile low lands that may be flooded at certain stages. In high rainfall zones, irrigation is less important for

\footnotetext{
${ }^{1}$ According to the World Commission on Dams, a key difference between a barrage and a dam is that a dam is built for water storage in a reservoir, which raises the level of water significantly while a barrage is generally built for diverting water.
} 
rice than other crops whereas more rainfall disrupts irrigated rice. The study states of IGP together account for at least $55 \%$ of rice output in India, among them, Uttar Pradesh (14\%), Punjab (13\%) and West Bengal (12\%) leading the country. Being an essential staple in the country, rice is privileged with government support in the market. The same states also grow other food and cash crops in the season, mostly coarse cereals, cotton and sugarcane in the western and central parts, jute in the east and vegetables and pulses all over.

\subsection{River Basins, Hydrology and the spatial nexus}

IGP in India is made up of rivers Indus in the North-West and Brahmaputra in North-East both of which originate in China (Tibet) and rivers Ganga and Yamuna in the North both arising from India (Uttarakhand). Starting from a glacier as Bhagirathi, river Ganga joins streams Mandakini and Alaknanda and flows south-east according to the slopes, draining the states Uttarakhand, Uttar Pradesh, Bihar, and finally West Bengal, where it branches off to reach the Bay of Bengal as rivers Bhagirathi and Hooghly at Ganga-Sagar in West Bengal and also enter Bangladesh as river Padma. River Yamuna the large tributary of Ganga passes through Uttarakhand, Himachal Pradesh, Haryana, Uttar Pradesh, Madhya Pradesh and Delhi to meet Ganga at Prayagraj, earlier Allahabad, in Uttar Pradesh.

Originating near Manas Sarovar and fed by precipitation in the Himalayas, Karakorams and the Hindu-Kush mountains, Indus is one of the longest rivers of South Asia. Entering India at Ladakh, till recently a part of the J\&K state ${ }^{2}$, it flows into Pakistan where much of the main river lies. Of its five principal tributaries in India, Satluj, Beas and Ravi help in irrigating a number of Indian states while waters of Indus and the two western tributaries Jhelum and Chenab are allocated to Pakistan where the Indus system is the most important source of irrigation. Satluj arises in Tibet while the other four start in India's Himalayan states Himachal Pradesh and J\&K. Chenab and Jhelum drain J\&K, Beas, Satluj and Ravi drain Punjab while Himachal Pradesh is watered by Beas, Chenab, and Satluj although interventions on the Indus valley make the irrigated catchment much larger. Beas and Satluj meet in Punjab in India but the others flow into Pakistan and all of them converge before reaching the Arabian Sea. The Indus Water Treaty (IWT) signed by India and Pakistan in 1960, guides water sharing between the two countries. In the large Indian catchment, the riparian states of Indus include not only Punjab, Himachal Pradesh and J\&K but also Rajasthan and Haryana.

Brahmaputra, a tributary of Ganga, has earlier versions before reaching Assam. Flowing eastward in China as Yarlung Tsangpo and entering Arunachal Pradesh westbound in India, it is joined by Himalayan rivers and followed by a later version in Bangladesh as Jamuna which meets the Padma basin. The long river, receiving many tributaries along its $2800 \mathrm{~km}$ course, drains multiple countries and its large Indian catchment covers Arunachal Pradesh, Assam, West Bengal, Meghalaya, Nagaland and Sikkim. The 900-kilometre-long Barak is another river of northeast, flowing through the states of Manipur, Nagaland, Mizoram and Assam into the Bay of Bengal via river Meghna in Bangladesh. Other trans-national rivers that meet the Meghna-Padma basin are Teesta, Mahananda and Jaldhaka, all draining the north-Bengal districts ${ }^{3}$ and Bangladesh. Land in the northeast is rich in surface water and has good capacity for groundwater recharge.

The vast IGP is hydrologically integrated at the surface and sub-surface levels and across national borders owing to the tributaries, mutual proximity and human behaviour. Tributaries link the Ganga basin with rain and snowfall in the Himalayas as also with rainfall in central India. In its upper stage, tributaries Ramganga, and the Yamuna and their own multiple tributaries add to the Ganga flow. Yamuna is fed by not only Himalayan Rivers but by Hindon, Ken, Betwa, Sindh and Chambal from the rocky central India and dry Rajasthan. Subsequently rivers Sone and Tamsa meet Ganga on the right bank and Kosi, Gomti, Ghaghara (Sarayu), Gandaki, Gandak and Mahananda on the left in Uttar Pradesh and Bihar. Rivers Ajoy, Damodar, Mayurakshi and Rupnarayan flow in Jharkhand and Bihar and confluence in West Bengal where Kangsabati also flows through several dry districts. The wild Damodar which, with its own tributary Barakar, passes through agriculturally and industrially rich parts of Jharkhand and West Bengal, is a tributary of Hooghly, which in turn is a distributary of Ganga. Bhairab, Jalangi, Mathabhanga are distributaries of the Padma River that enter West Bengalto join the Bhagirathi.

The Gandak and Gandaki also share basins with Nepal. Gandak, Gandaki, Brahmaputra and Kosi, with its tributaries (Sun, Arun) connect the IGP with China [17]. The rivers traversing the mountains are charged by snow melt or heavy rainfall, face steep gradients, carry enormous sediments and tend to change their courses. Mahananda enters Bangladesh twice in a loop and Jaldhaka also touches Bhutan. Constructions in India, Pakistan and China, changes in courses of the rivers like Ravi and shifts at the mouth create transnational water nexus in the Indus basin. Among IGP channels are also rivers Shipra of Madhya Pradesh, Banas in Rajasthan, Rihand in Chhattisgarh and Uttar Pradesh, North Koel in Jharkhand, Churni and Ichhamati in West Bengal, Bagmati of Nepal and Bihar that are all sub-tributaries of Ganga. Titas, Torsa, Surma, Kushyara and Barak of north-east India and Bangladesh, Mahananda of Bihar, West Bengal and

\footnotetext{
${ }^{2}$ Ladakh is now an Union Territory separate from J\&K (Jammu\& Kashmir) since 31 ${ }^{\text {st }}$ October, 2019.

${ }^{3}$ North Bengal districts are Darjeeling, Kalimpong, Jalpaiguri, Alipurduar, Coochbehar, North Dinajpur, South Dinajpur and Malda belonging to state West Bengal.
} 
Bangladesh, Manas of China, Bhutan and north-east India, Jaldhaka and Teesta of Sikkim, West Bengal and Bangladesh all confluence in the Meghna basin. Linked to Indus are upstream tributaries Zanskar, Shuru and Shyok which meet rivers Nubra and the Galwan in Ladakh in India, but many other rivers flow into Pakistan or Afghanistan after touching Ladakh. Independent of the main rivers in the IGP are Subarnarekha, Brahmani and South Koel of Jharkhand, Odisha and West Bengal and the seasonally inland rivers like Luni, Kantla, Ruparel and Ghaggar-Hakra of Rajasthan and Haryana.

\subsection{Interventions, complex Interfaces and Water management}

Ganga plains are prone to inundation. Floods are recurrent in the middle and lower reaches that are major hubs of agrarian population who resort to out-migration in distress and show aversion to risky monsoon farming [34]. In the northeast, floods are particularly severe due to heavy rainfall, congestion, erosion and water spilling over the river banks. Poor drainage, proliferation and deepening of wells and shifts in river courses perturb the Indus basin in the northwest where flood is a lesser problem but sediments from Karakoram, the western Himalayas and the numerous dams create calamities for Pakistan. Historically, intervention meant primarily for flood control, was by holding, extracting and diverting natural rain water by gravity-flow but the methods became more complex with multiple demands as river water management became institutionalized with centralized and bureaucratic procedures. The interventions now involve storing water from excess rainfall in a year for redistribution and use in the future if and where needed. The stored water in a reservoir, often equipped with a hydro-power plant installed, is also useful for generating electricity. However, there is a limit to the holding capacity, beyond which a dam can breach, resulting in a flood that is more devastating than rainfall would create.

The oldest perennial intervention is the (Upper) Ganga Canal taking off from Uttarakhand and falling into Yamuna in Uttar Pradesh. The diverted Ganga water then irrigates a number of districts of Uttar Pradesh. Tehri in Uttarakhand is one of the world's highest dams. Operational from 2004, its reservoir collects water from Bhagirathi. Tehri Dam, Bhimgoda barrage, Ramganga feeder (Kalagarh) dam, barrages at Bijnore, Kanpur and Narora are interventions to divert Ganga water upstream of Prayagraj, where Ganga is again recharged by Yamuna. Dakpathar, Hathnikund, Wazirabad, Indraprastha, Okhla, Gokul are barrages on Yamuna River, managed by multiple state governments. With many branches, the Agra and the Munak canals and the Western and Eastern Yamuna canals irrigate vast tracts of land in Haryana and Uttar Pradesh. Water is allocated also to Himachal Pradesh, Uttarakhand, Rajasthan and Delhi for different purposes. Nearly a third of the Ganga dams are in the contiguous states Madhya Pradesh and Chattisgarh.

Further downstream, Ganga is enriched by more rivers and intervened by several multipurpose projects. Ban-Sagar dam on Sone in Madhya Pradesh, Rihand valley project (RVP) ${ }^{4}$ on a tributary of Sone in Uttar Pradesh, Matatila and Rajghat on Betwa river between Madhya Pradesh and Uttar Pradesh, Chambal river project (CRP) ${ }^{5}$ between Rajasthan and Madhya Pradesh and the Gandak project between Nepal and India help to control Ganga water distribution among Uttar Pradesh, Madhya Pradesh, Chhattisgarh, Rajasthan and parts of Bihar in India. With four dams, one barrage, six power plants, four reservoirs and a network of canals, the Damodar valley project (DVC), though primarily aimed for controlling floods, is also multipurpose, irrigating ten districts of Jharkhand and six of West Bengal. Mayurakshi project (Massanjore) in Jharkhand and West Bengal and Mukutmanipur dam on Kangsabati River in West Bengal have been functioning for decades. Farakka barrage for desilting the Hooghly port and Teesta barrages for power generation and flood control have created longstanding disputes with Bangladesh over water allocation. Hydroelectric projects are functional in the fertile valley of river Jaldhaka innorth-Bengal. Right and left banks canals of Damodar, Mayurakshi and Kangsabati projects, Medinipur canal from the Kaise River and Eden canal from Damodar are major canals in West Bengal though the share of surface water in irrigation has reduced to the minimal in the state.

Environmental resistance and geo-political discords make both Indus and Brahmaputra valleys sensitive sites. Planned in colonial times, the Bhakra-Nangal (BN) multipurpose dams in Himachal Pradesh were described as "New Temple of Resurgent India” by the first Prime Minister of India. The associated Gobind Sagar is the second largest reservoir in India. With four spillway ${ }^{6}$ gates, Bhakra Dam on the Sutluj River holds excess monsoon waters for regulated release. Bhakra Canal irrigates Punjab, Haryana, and Rajasthan. The power generated is distributed among six partner states helping ground water harvesting (Figure2). Beas water, also stored in Pandoh Lake, irrigates Punjab and Haryana. The Ranjit Sagar Dam (Thein Dam), on River Ravi has much of its reservoir in J\&K. Starting as Rajasthan feeder canal from the Harike Barrage, Indira Gandhi Canal (earlier Rajasthan Canal) flows through Punjab, Haryana and seven desert districts of Rajasthan, bringing Himalayan waters from Sutluj, Beas and Ravi for irrigation. Punjab is irrigated not only by the rivers but also Sirhind and Sirhind feeder canals, Eastern canal, Upper Bari Doab canal, Bhakra canal and Bist Doab canal. Eastern Rajasthan is served by Jakham dam and Mahi Bajaj sagar and shares water and power

\footnotetext{
${ }^{4}$ Govind Ballabh Pant Sagar, Rihand dam.

5 Rana Pratap Sagar, Gandhi Sagar and Jawahar Sahar (Kota), Kota barrage.

${ }^{6}$ Spillway is a passage for surplus water over or around a dam when the reservoir itself is full. They are safety features for the dam.
} 
from CRP with Madhya Pradesh. On the swift and turbulent Brahmaputra, permanent structures are not easy to build while gravity flow surface water diversion projects are expensive. Electrical, diesel or solar power is demanded by surface water, ground water, drip or lift irrigation in the uneven terrain but irrigation potential is highly underutilized in Assam which has only few projects completed (Longa). Due to high cost, changes in river direction, siltation and administrative shortfalls, many projects are under construction for years or remain in paper (Dibang, Dhansiri, Champamati, Kameng). Although the Himalayan northeast including Sikkim and North Bengal is known as the "Power House" of India, power trading with other states and countries like Bangladesh and Bhutan have been limited owing to environmental and engineering setbacks and lack of transmission lines [18].

Canals once dominated the Indian irrigation scene ( $40 \%$ of total) but growing ground water irrigation surpassed that share by 1980’s. Between 1996-97 and 2002-03, only wells contributed to India's irrigation expansion. The transition in the irrigation regime is described as a shift from "gravity" to water "scavenging" and from "centralized" to increasingly "atomistic" water management [19, 1, 20]. With tube-wells being deepened to access groundwater, the Indus basin in both India and Pakistan became a most depleted basin in the world [21, 22]. Eastern states were no different. Three large surface water projects failed in West Bengal, despite abundant rainfall and alluvial aquifers, while shallow tube-wells grew manifold [23].

Water management is crucial for agriculture. Past rainfall moistens the soil and recharges ground water. Water from rainfall elsewhere, current and past, is stored in reservoirs built around rivers to be used when and where needed while avoiding adverse flooding and also for generating power from water heads but controlling nature has never been costless nor perfectly efficient despite all the administrative institutions for water sharing ${ }^{7}$. Depriving rivers of space, dams are increasingly seen as "counter-productive" as civil engineering interventions lose credibility. Dams have caused prolonged human displacement, inter-state conflicts and litigations over land acquisition but did not relieve the basins of floods. Rather, sudden releases of dam water are more often responsible for floods so that "brimming" dams from rainfall somewhere fail to cheer farmers [25]. Land use changes they motivate within agriculture create further ecological complexities. Water shortages strain the farmers when water is diverted by barrages. By its locational advantage, Haryana, receives water and power from both Yamuna-Ganga basin and the Bhakra system of Indus basin. Yet, water is an issue of conflict for the state. Indian dams also face obsolescence but replacing them with advanced technology is an expensive option. Today majority of the dams serve mostly as hydropower generators which in turn promote well irrigation [26, 27].

Digging of private wells too has created threats of inequity, water injustice and depletion of ground water. Contamination of drinking water with nitrites, salts, fertilizers and pesticides and even arsenic from deeper levels of earth is associated with overdraft ${ }^{8}$. Compaction of aquifers, de-stabilsation and irreversible subsidence of land that endangers roads and bridges and enhances use of energy are indirect costs [28]. Ground water reserves are not independent of surface water management because, on deepening, wells draw from streams and rivers laterally and cause salt water intrusion in coastal belts. While diversion of upstream Ganga water is blamed for water shortage in northwestern India, dams serve to regenerate it downstream after intense seepage due to ground water irrigation. Surface water projects help in mitigating if not preventing floods, redistributing surplus water across rivers, recharging groundwater, energizing pumps and deterring pest infestation [29].

Climate change is projected to make temperatures rise, seasons ill-defined and rainfall regionally erratic and intense. Over the 21st century, significant alteration of hydro-climatic regime is expected. It is widely agreed that the Indo-Gangetic basin is likely to experience increased water availability from snow-melt up to around 2030 but face gradual reductions thereafter. The future of monsoon rainfall is extremely uncertain. Parts of the Indo-Gangetic basin are already receiving less rain than in the past [19, 30]. Sensitive and adaptive water management has become essential in light of the threat. Inter-dependence between public and private investment on irrigation and a case for conjunctive use of surface water and ground water irrigation have long been recognized [31] so that the inter-relations can be exploited by design rather than human economic responses [32]. Artificial ground water recharge in the Indus basin, modification of the drain beds, recovering abandoned or lost river channels and revitalizing village ponds and tanks with spill-away technology are ways now used to address ground water depletion. Exploration of deep-seated aquifers of IGP is suggested [33]. India's National Water Policy [6] underscores the maintenance of hydrological structures including river basins and recognizes the urgency for understanding the dynamics of flows of both surface and ground water, mapping

\footnotetext{
${ }^{7}$ River Boards Act 1956 created Bhakra Beas Management, Upper Yamuna river Board (UYRB), Brahmaputra Board (1980), Ganga flood control committee (1972), the DVC and Betwa river Board that arbitrate water and power sharing, flood control, minimizing siltation and erosion among the basin states. Central Water Commission has started flood-forecasting in the basin. Water management is also an aspect of inter-national cooperation as between India and Nepal, Bangladesh [24] and Pakistan.

${ }^{8}$ Groundwater overdraft occurs when groundwater use exceeds the amount of recharge into an aquifer, which leads to a dangerous decline in groundwater level.
} 
of aquifers and recharge zones ${ }^{9}$. Early warning of floods and droughts, zoning of vulnerable areas from cultivation, institutionalized disaster management, incentive for cropping pattern changes, crop insurance and exchange of information across border are gaining primacy over physical interventions [34, 35, 36].

\section{Method}

The analysis uses an econometric model to estimate production of a crop.

$$
Y=f\left(X_{1}, X_{2}, X_{3}, X_{4}, \ldots \ldots X_{i}\right)+e
$$

In which $Y$ is the dependent variable indicative of production and $X$ is a set of explanatory variable, considered relevant based on theory. The marginal effect (ME) of a change in any factor $i$ is mathematically given by

$$
d Y / d X_{i}
$$

where

$$
\text { Now, } \mathrm{d}(Y)=\Sigma\left(\left(d Y / d X_{i}\right)^{*} \Delta\left(X_{i}\right)\right)
$$

assuming $e$ is small. ME is used to assess the effect of a variable as favourable (positive) or adverse (negative)

\subsection{Seasonality, Spatiality and rainfall shortage in recent times}

The spatial unit of rainfall is the MET of which 21 are considered (see Table 1). Located in IGP and its periphery, they are primarily chosen for their rainfall effects on the study states based on both proximity and river linkages but the final specification is decided at model selection. Presuming borders of METS and political states do not coincide sharply an adjoining MET expectedly has commonality of climate with border districts. Rigid apportionment of growing season is also simplistic today when improvement of resilient seeds has made calendars more dynamic and adaptive to variable weather conditions and enabled late or re-sowing of acreage unsown or destroyed by disasters. Changing patterns and intensity of cropping tend to redefine the crop seasons. Specifications made of the seasons are less restrained and broader than the traditional calendars and covers 27 months (January of previous year to March of following year).

Table 1. Met region abbreviations

\begin{tabular}{cc}
\hline AR & Arunachal Pradesh \\
AM & Assam \& Meghalaya \\
EH & Nagaland, Manipur, Mizoram, Tripura \\
HW & Sub-Himalayan W. Bengal \& Sikkim \\
GW & Gangetic West Bengal \\
OD & Orissa \\
JH & Jharkhand \\
BH & Bihar \\
EU & East Uttar Pradesh \\
WU & West Uttar Pradesh \\
UT & Uttarakhand \\
HC & Haryana Chandigarh And Delhi \\
PJ & Punjab \\
HP & Himachal Pradesh \\
JK & Jammu \& Kashmir \\
WR & West Rajasthan \\
ER & East Rajasthan \\
EM & West Madhya Pradesh \\
WM & East Madhya Pradesh \\
CA & Coastal Andhra Pradesh \\
CH & Chhattisgarh \\
\hline
\end{tabular}

Previous year/pre-season rainfall (PSR): January to December of previous calendar year.

\footnotetext{
${ }^{9}$ Various State Government Agencies in limited manner deal with specific water issues and no department is in control or possession of complete information on the rivers.
} 
Early-season rainfall (ESR): January to April, traditionally the pre-kharif period.

Mid-season rainfall (MSR): Rainfall in May to September, the monsoon months.

Late-season rainfall (LSR): October to March, post-monsoon and harvest season.

\subsection{Model to explain crop Production}

The model is specified in two stages. In the first stage area under a crop is estimated considering substitution possibilities among crops and with past acreage as the dynamic trend term [37]. In the second stage its yield is estimated considering weather parameters, economic variable with input cost and substitution possibility and a time trend. Production is the product of area and yield.

Adaptive expectations as well as rationality [38] underlie subjective expectations formed about crop price in Rs. per $\mathrm{Kg}$ or its returns in Rs. per hectare to be fetched only after harvest. Possible substitute crops are identified using pattern and calendar of cropping in the region and after each of them is considered individually, only those with statistically significant coefficients are retained as competing crops. The average of the identified competing crop prices or returns is used in the equation. The model incorporates water variables (W) shaped by rainfall by itself in various hydrologically linked regions but rainfall can be qualified by irrigation which aims to bring control over the water. Irrigation (IRG) measured as land area under different sources (Figure 1), however, is basically infrastructure and has limited variation over time. In the case of the yield per hectare, the interacted water variable is standardized (deflated) by the crop area as estimated in the first stage. For simplicity and to allow variables to take zero values, the model is estimated in linear form, but allowing quadratic and interaction terms. Intense use of maps of crop clusters, river basins and METs are made when specifying the model.

For any crop

$$
\begin{aligned}
& A_{t}=a_{0}+a_{1} A_{t-1}+a_{2} P_{t}+\left(\sum a_{3 j} * W_{t}^{j}\right)+\sum a_{4 s} I R G_{t s}+\sum a_{5 z} C_{t z}, \ldots \ldots \ldots \ldots \ldots \ldots \ldots(\text { (4) } \\
& Y_{t}=b_{0}+b_{1} t+b_{2} p_{t}+b_{3} p_{t}^{c}+\sum\left(b_{4 j} * w_{t}^{j}+\sum b_{5 s} I R G_{t s}+\sum b_{6 m M f} * T X_{t m M f}+\sum b_{7 m M f} * T N_{t m M f}+\sum b_{8 k} D_{t k}+\right. \\
& \sum b_{9 m M} * R_{t m M}^{2}++\sum b_{10 z} C_{t z},
\end{aligned}
$$

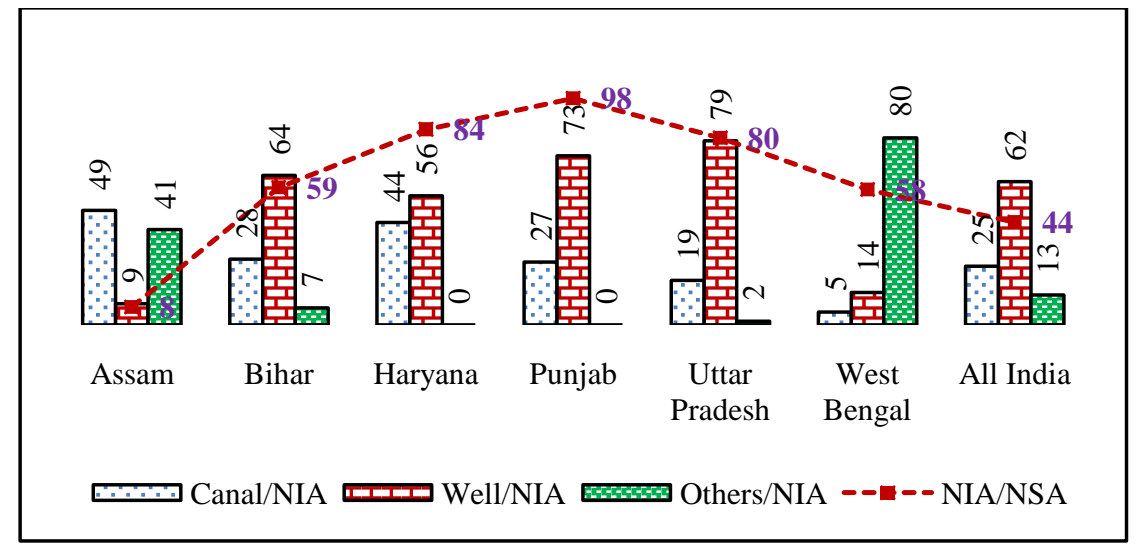

Figure 1. Share (\%) of irrigated area by sources in the NIA and share (\%) of NIA in NSA

(NIA = Net irrigated area total, NSA $=$ Net Sown Area)

$A_{\mathrm{t}}=$ area in hectares under study crop, $Y_{\mathrm{t}}=$ yield $(\mathrm{Kg})$ per hectare of study crop, $P_{\mathrm{t}}=P_{\mathrm{t} 1}$ or $P_{\mathrm{t} 2}$ and $p_{\mathrm{t}}=p_{\mathrm{t} 1}$ or $p_{\mathrm{t} 2}$ in alternate specifications where $\mathrm{P}_{t 1}=\left(W P_{t m}\right) /\left(W P_{t m}^{c}\right), P_{t 2}=\left(W P_{t m} * Y_{t-1}\right) /\left(W P_{t m}^{c} * Y_{t-1}^{c}\right), p_{t 1}=\left(W P_{t m}\right) /\left(W P_{t}^{F}\right), p_{t 2}=\left(W P_{t m} *\right.$ $\left.Y_{t-1}\right) /\left(W P_{t}^{F}\right)$

$W P_{t}$ is the corresponding wholesale price (WSP) of crop in previous year, or latest MSP or the average of both, $W_{t}^{j}=$ $W_{t 1}^{j}$ or $W_{t 2}^{j}$ and $w_{t}^{j}=w_{t 1}^{j}$ or $w_{t 2}^{j}$ in alternate specifications where

$$
W_{t 1}^{j}=R_{t M m}, W_{t 2}^{j}=\left(R_{t M m}\right) * I_{t s} \text { and } w_{t}^{j}=W_{t}^{j} / \exp \left(\mathrm{A}_{\mathrm{t}}\right)
$$

Where $\mathrm{R}_{\mathrm{tMm}}=$ rainfall averaged across different alternate sets of $\mathrm{M}$ and $\mathrm{m}$

$\mathrm{IRG}_{\mathrm{ts}}$ is command area under any irrigation sources

$\mathrm{TX}_{\mathrm{tmMf}}=$ maximum of daily temperatures or their average across $\mathrm{M}$, $\mathrm{m}$ and $\mathrm{f}$ of growing season

$\mathrm{TN}_{\mathrm{tmMf}}=$ minimum of daily temperatures or their average across $\mathrm{M}, \mathrm{m}$ and $\mathrm{f}$ of growing season

$\mathrm{D}_{\mathrm{k}}=$ kth dummy variable for any known change in technology or policy,

$\mathrm{C}_{\mathrm{tz}}=$ any other relevant $\mathrm{z}^{\mathrm{th}}$ variable 
Subscripts: $t$ is year (2000-01 onwards), $M=$ met region $(1,2 \ldots 21), m=$ month $(1 \ldots 27), f=$ fortnight $(1,2){\text { in any } m^{\text {th }}}$ growing month, $\mathrm{s}=$ source of irrigation (Canal $=1$ Tube well $=2$, Canal + Tube well $=3$, all others $=4$, total $=5$ ). Superscripts: $c=$ competing crop or crops $(1,2, \ldots n), F=$ fertilizer $(N P K), j=j^{\text {th }}$ water variable identified by season and region of rainfall, exp = expected value of crop area = area estimated in equation (1). Error (E) is the difference (\%) of estimate over observed officially recorded value from data.

In vast hydrologically linked spatial expanses (section 3) with temporal storage possible, the large number of rainfall variables reduces degrees of freedom and enhances the possibility of multicollinearity caused by spatial interdependence of weather. Data reduction is accomplished by checking the statistical effect of each rainfall variable at a time and averaging the causative variables categorized by the four seasons to make up a set of rainfall values in a water variable with acumulative effect in any specific direction. The sample period is fairly contemporary at 2000-01 to 2017-18. Autocorrelation is corrected where indicated by DW statistic, stability of the equation is tested by comparing the coefficients model estimated after dropping the last sample year the errors are examined for stationarity by Dickey-Fuller (DF) test statistics. Selection of the equation for further analysis is made keeping the following mathematical and economic conditions on diagnostics:

$\operatorname{Abs}\left[\mathrm{a}_{1}\right]<1, \mathrm{a}_{2}>0, \mathrm{~b} 2>0, \mathrm{~b}_{3}<0, \mathrm{~b}_{9}<0$,

All t-statistics (except $\mathrm{a}_{1}$ ) of coefficients $>1.96$ (level of significant at $5 \%$ )

$\mathrm{R}_{\mathrm{bar}}{ }^{2}>0.90$, DW near 2 and $\mathrm{E}$ is between $+5 \%$ and $-5 \%$ in the sample period with the direction of estimate matching by and large with data. The predictive power of the model is also assessed by matching a one-step forward forecast for 2018-19 with the actual data available.

Although no constraint is demanded on other coefficients, interpretations are important. More of a water variable will have a favourable impact on area of a crop needy of water but for crops with moderate demand for water, a negative effect can indicate either damage to planting or an incentive to allocate acreage towards alternative water demanding crops. For crop yield, a positive effect is the ideal while a negative coefficient is a sign of shortfalls in water management, especially poor drainage. The effect of the water variable, especially of past rainfall (PSR) implicitly signifies the management of rain and river water. An interaction between PSR and canal, ideally positive, is expected though river water flow under gravity or the sale of hydro-power by grid (Figure 2) for ground water irrigation in the study state can act as other conduits. Temperature effect reflects agronomic necessities for fruition at different growth phases. Time trend will be positive for yield in the presence of technical progress not captured by the other variables in the model while the dynamic lagged acreage variable in the area equation reflects the effort to catch up and adjust to desired acreage by farmers. Dummy variables for National Food Security Mission, National Food Security Act and similar other policy launches are represented by Dummy variables. The results based on estimated equations are summarized in Table 2 and Table 3.

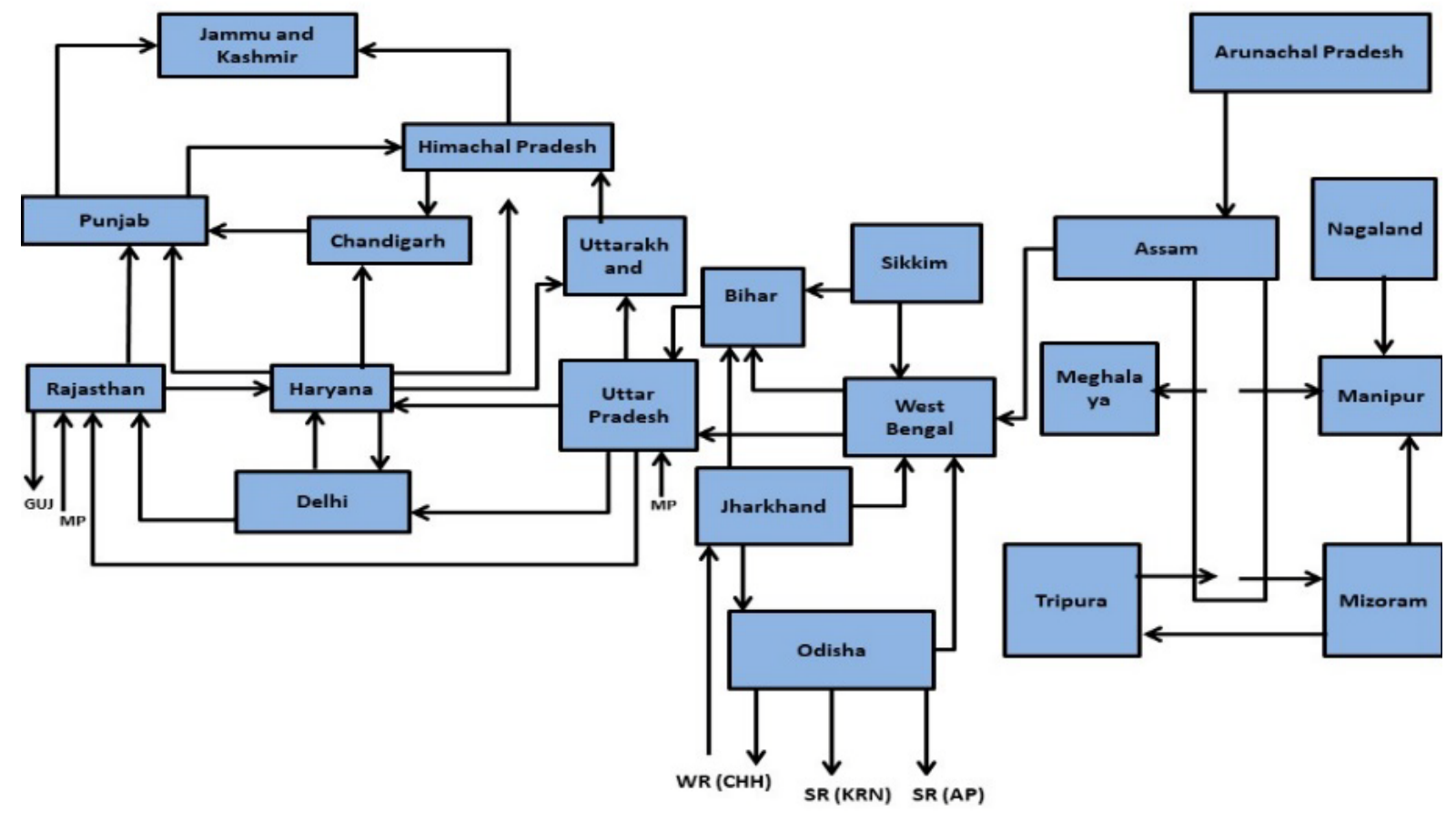

Figure 2. Inter-state power supply scenarios. 
Table 2. Economic, Spatial Rainfall and Irrigation factors to acreage equation

\begin{tabular}{|c|c|c|c|c|c|c|c|c|c|}
\hline \multirow{3}{*}{ State } & Economy & \multirow{3}{*}{ Trend } & \multicolumn{6}{|c|}{ Rainfall } & \multirow{3}{*}{ Irrigation } \\
\hline & \multirow{2}{*}{ Price* } & & \multicolumn{2}{|c|}{ PSR } & \multicolumn{2}{|c|}{ ESR } & \multicolumn{2}{|l|}{ MSR } & \\
\hline & & & +ve & -ve & +ve & -ve & + ve & -ve & \\
\hline \multirow{2}{*}{ Assam } & WSP, MSP & \multirow{2}{*}{ +ve } & \multirow{2}{*}{$(\mathrm{GW}, \mathrm{BH})^{4}$} & \multirow{2}{*}{ AR, EH, AM, HW } & \multirow{2}{*}{$\mathrm{AM}$} & \multirow{2}{*}{$\mathrm{AR}$} & \multirow{2}{*}{$\begin{array}{c}\mathrm{EH}, \mathrm{GW}, \\
\mathrm{AM}, \mathrm{AR}, \mathrm{BH}^{5}\end{array}$} & & \multirow{2}{*}{$4^{+}$} \\
\hline & mg, on, sc & & & & & & & & \\
\hline \multirow{2}{*}{ Bihar } & MSP & \multirow{2}{*}{-ve } & \multirow{2}{*}{$\begin{array}{c}\mathrm{EU}^{1}, \mathrm{CH}^{1}, \mathrm{JH}^{2}, \\
\mathrm{HW}^{5}\end{array}$} & \multirow{2}{*}{$\mathrm{BH}^{1}$} & \multirow{2}{*}{ HW, WU } & & \multirow{2}{*}{ BH, JH } & \multirow{2}{*}{$\mathrm{AM}, \mathrm{GW}$} & \\
\hline & ar, mg & & & & & & & & \\
\hline \multirow{2}{*}{ Haryana } & WSP, MSP & \multirow{2}{*}{ +ve } & \multirow{2}{*}{$\mathrm{JK}^{1},(\mathrm{WR}, \mathrm{ER})^{1}$} & \multirow{2}{*}{$\begin{array}{c}\text { PJ, HP, HC, UT, } \\
\text { WU }\end{array}$} & \multirow{2}{*}{$\begin{array}{l}\mathrm{WR},(\mathrm{JK}, \mathrm{PJ}, \\
\mathrm{UT})^{3}\end{array}$} & \multirow{2}{*}{$\begin{array}{c}(\mathrm{HC}, \mathrm{WU} \\
\mathrm{HP})^{1}\end{array}$} & \multirow{2}{*}{$\begin{array}{l}\text { (ER, WR, HC, HP, } \\
\text { JK, UT, WU, JK) }\end{array}$} & & \\
\hline & bj, ct, ar, sc & & & & & & & & \\
\hline \multirow{2}{*}{ Punjab } & WSP, MSP & \multirow{2}{*}{ +ve } & \multirow{2}{*}{$\mathrm{JK}^{1}$, } & \multirow{2}{*}{$\mathrm{UT}^{1}, \mathrm{HC}^{1}, \mathrm{HP}^{1}$} & \multirow{2}{*}{$(\mathrm{UT}, \mathrm{HC}, \mathrm{JK})^{2}$} & \multirow{2}{*}{$(\mathrm{HP}, \mathrm{PJ})^{1}$} & \multirow{2}{*}{$(\mathrm{PJ}, \mathrm{HP})^{1}$} & $H C^{1}$ & \\
\hline & $\mathrm{ct}, \mathrm{mg}$ & & & & & & & 110 & \\
\hline Uttar Pradesh & WSP, MSP & tve & $\mathrm{GW}^{2},(\mathrm{EU}$, & $\mathrm{UT}^{1} \mathrm{IH}^{1}$ & & & EM, JH, CH, UT, & $\mathrm{BH}$ & \\
\hline Silat 1 1avesin & jw, on, ch & re & $\mathrm{BH})^{1}$ & (1) & & & ER, EU, WU & DH & \\
\hline & WSP, MSP & & $(C$ & $\mathrm{OD},(\mathrm{BH}, \mathrm{AM}$, & $(\mathrm{BH}, \mathrm{EU})^{4}$, & & & & \\
\hline West Dengal & jt, ar, mg & +ve & $(\mathrm{CH}, \mathrm{JH})$ & HW, GW) $)^{5}$ & $(\mathrm{OD}, \mathrm{CH})^{5}$ & GW & AM, AR, HW & CA & 4 \\
\hline
\end{tabular}

Notes: * Crop prices are followed by prices of competing crops. WSP=wholesale price of crop, MSP=minimum support price of crop, Substitute crop: mg=Moong, ar=Arhar, sc=Sugarcane, jw= Jowar, bj=Bajra, ct=Cotton, jt= Jute, ch=Chilli, on=Onion. Rainfall: PSR= Previous calendar year, ESR= Jan-Apr, MSR= May-Sept, LSR= Oct-March. 1: Canal (CL), 2: Well (WL), 3: Canal + Well, 4: Oth (OT), 5: All irrigation. Sample: 2000-01 to 2017-18. MET regions: See Table 1.

Table 3. Economic, Spatial Rainfall and Irrigation factors to yield equation

\begin{tabular}{|c|c|c|c|c|c|c|c|c|c|c|c|c|}
\hline \multirow{3}{*}{ State } & \multirow{3}{*}{$\begin{array}{c}\text { Economy } \\
\text { Price }\end{array}$} & \multicolumn{8}{|c|}{ Spatial Rainfall } & \multirow{3}{*}{$\begin{array}{l}\text { Irriga- } \\
\text { tion }\end{array}$} & \multirow{2}{*}{\multicolumn{2}{|c|}{ Temperature }} \\
\hline & & \multicolumn{2}{|c|}{ PSR } & \multicolumn{2}{|c|}{ ESR } & \multicolumn{2}{|c|}{ MSR } & \multicolumn{2}{|c|}{ LSR } & & & \\
\hline & & +ve & -ve & +ve & -ve & +ve & -ve & +ve & -ve & & +ve & -ve \\
\hline Assam & WSP, MSP & $\begin{array}{c}\text { EH, AM, JH, } \\
\text { GW }\end{array}$ & & & $\mathrm{AM}$ & $\begin{array}{c}\mathrm{HW}, \mathrm{GW}, \\
\mathrm{EH}, \mathrm{BH}\end{array}$ & AR, JH, AM & HW, EH & $\mathrm{AR}$ & $5+$ & & Dc2_Mx \\
\hline Bihar & WSP, MSP & $\underset{\mathrm{EU}^{1}}{(\mathrm{GW}, \mathrm{HW})^{1}}$ & $\mathrm{BH}^{1}$ & HW, GW & & HW, EU, BH & AR, AM, CH & & $\begin{array}{c}\mathrm{HW}, \mathrm{JH}, \\
\mathrm{BH}\end{array}$ & & Fb2_Mn(1) & \\
\hline Haryana & MSP & $\begin{array}{c}\text { (UT, JK, HP, } \\
\text { HC, WR) }\end{array}$ & $\mathrm{EU}^{1}, \mathrm{PJ}$ & $\begin{array}{c}\text { (HC, UT, } \\
\text { WU })^{2}, \\
\mathrm{PJ}^{1}\end{array}$ & $\begin{array}{l}\mathrm{HP} \\
\mathrm{ER}\end{array}$ & WR & PJ, HC & & & $5+$ & Sp2_Mn & \\
\hline Punjab & MSP & $\begin{array}{c}(\mathrm{WR}, \mathrm{ER})^{1} \text {, } \\
(\mathrm{HP}, \mathrm{UT})^{1}\end{array}$ & $\begin{array}{c}\text { PJ, HC, } \\
\text { JK, WM, } \\
\text { EM }\end{array}$ & JK, PJ & & $\begin{array}{c}(\mathrm{PJ}, \mathrm{JK}, \mathrm{HC} \\
\mathrm{WR})^{5}\end{array}$ & UT & PJ, WR, & $\begin{array}{l}\text { HP, JK, } \\
\text { EU, UT }\end{array}$ & & $\begin{array}{l}\text { Ag1_Mx } \\
\text { Dc1_Mn }\end{array}$ & \\
\hline $\begin{array}{l}\text { Uttar } \\
\text { Pradesh }\end{array}$ & WSP, MSP & $\mathrm{PJ}^{1}, \mathrm{WM}^{1}$ & UT, HC & & WU & $\begin{array}{l}\mathrm{EU}, \mathrm{WU}, \\
\mathrm{BH}^{1}, \mathrm{EM}^{1}\end{array}$ & PJ, HP, HC & $\mathrm{BH}, \mathrm{CH}$ & WM & & & \\
\hline $\begin{array}{l}\text { West } \\
\text { Bengal }\end{array}$ & WSP, MSP & $\mathrm{HW}, \mathrm{CH}^{5}$ & $\begin{array}{l}\text { BH, EU, } \\
\text { AR }\end{array}$ & $\mathrm{EU}, \mathrm{AM}^{5}$ & & $\begin{array}{c}\text { HW, GW, } \\
\text { AM }\end{array}$ & $\mathrm{BH}, \mathrm{JH}$ & HW & GW, JH & & Nv1_Mx & \\
\hline
\end{tabular}

\section{Findings}

Both market price (WSP) and administered price (MSP) drove acreage sown with rice, except that WSP is not found significant in Bihar where markets are deregulated which makes paucity of price information possible. Pulses are major competitors of acreage but cash crops cotton or jute emerged as competitors in Punjab, Haryana and West Bengal respectively, sugarcane and vegetables in Assam, Uttar Pradesh and Haryana and coarse cereals in two of the states. For yield only MSP is found significant in Punjab and Haryana and no substitute crop is identified for allocation of resources. The selection of the "returns per hectare" variable as the economic incentive in all cases of acreage equation and all but Assam in the yield equation reflects the dynamics that rice yield is still undergoing years after the agrarian revolution. Heat matters but in most cases, higher (night/minimum) temperature improves rice yield and only in two eastern states West Bengal and Assam cooler December could have helped. Rainfall effect is a combined effect of both positive and negative responses to rainfall in various MET regions in and outside the study states and especially in the mountains. No time trend is found in any yield equation nor was any dummy variable found to produce a significant coefficient. With a negative coefficient of the lagged term, acreage is found to over adjust, shooting above its desired level only in Bihar which operates under sharp weather vagary. Independent of rainfall, effect of the irrigation structure 
is favourable, though limited to Assam and Haryana for rice yield, but on area, the effect is favourable in Assam and adverse in West Bengal and the type of influential irrigation is not specific to canal or tube-well. Error (E) is fairly low, also accounting for the direction changes in the sample period. For forecasts beyond the sample year, the error is less than 5\% (Figure 3). The coefficients appearing in the selected specifications are all statistically significant, at even $1 \%$ in a number of cases and at $5 \%$ level in others.

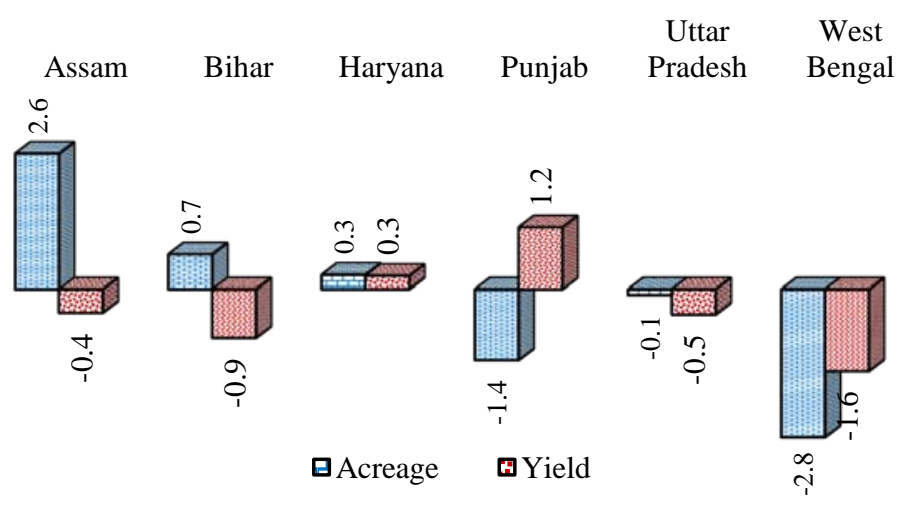

Figure 3. Validation for forecast error (\%) for acreage and yield in 2018-19.

\subsection{Rainfall impact: Temporal and Spatial}

PSR: A close nexus is found among BH, GW and the Himalayan Mets AM, EH and HW in determining rice acreage in the east and among PJ, HC, WR and the mountain METS of JK, UT and HP in the west. By and large, Himalayan rainfall of the past tended to reduce rice acreage, JK being an important aberration but yield in many cases benefited from previous rainfall in EH, HW, UT, JK and even HP. In the Punjab-Haryana belt both acreage and yield were enhanced by rainfall in Rajasthan but high rainfall of previous year in HC, PJ and HP discouraged planting which means that regional rainfall of the belt did not help production. Planting in the belt was supported by rains in JK, ER and WR. In fact, except for the large state Uttar Pradesh, sprawled from west to east, past rainfall in the study state was not acreage-enhancing but rainfall in neighbouring plain states helped sowing of rice in Bihar (EU, JH, CH and HW), Uttar Pradesh $(\mathrm{BH})$ and West Bengal $(\mathrm{JH}, \mathrm{CH})$. On the contrary, rainfall in proximate plain states hurt area in Assam (HW), Uttar Pradesh (JH), and West Bengal (AM, BH and OD) apart from the mutually adverse effect of PJ and HC. For yield, on the contrary, the past rainfall in local and neighbouring regions have mostly proved beneficial as in Assam (EH, AM), Bihar (GW, HW, EU), Haryana (HC, HP, UT, JK, WR), Punjab (ER, WR, HP, UT) and Uttar Pradesh (WM, PJ). Although proximity and altitude have generally mattered, basin effect could be far-reaching such as BH's rainfall affecting area in Assam, GW's effect on Uttar Pradesh and yield in Punjab being hurt by rainfall in WM and EM.

Access to water and its implications were affected by irrigation in many cases. Canal irrigation supported the usefulness of rainfall in EU and $\mathrm{CH}$ to promote rice cultivation in Bihar, combined with rainfall in different regions to encourage planting in Haryana and Punjab and that in EU and BH to support planting in Uttar Pradesh. Tube wells have helped to utilize water from past rainfall for planting in Assam, Uttar Pradesh and West Bengal, though irrigation other than canals and tube wells and total irrigation helped in Assam and West Bengal. Yield in West Bengal was supported by past rainfall in Chhattisgarh with all kinds of irrigation. Local and neighbouring rainfall helped in Assam by only gravity and for the rest, in Punjab, Haryana Bihar and Uttar Pradesh, canals had the strongest role in utilizing rainfall water. But some of the negative effects of rainfall are also associated with canal irrigation not only for acreage but also yield in Bihar and Haryana.

ESR: In many states rice planting, known to precede the arrival of monsoon, depends on irrigation, western disturbances and local thunder storms. Even for traditional seasonality, sowing is affected by excess or deficiency of soil moisture. Early rainfall including Himalayan rainfall, is found to be generally helpful for both the east and the west with canals and tube wells. Adverse rainfall effect of HP and useful effect of JK for rice acreage in the Punjab-Haryana belt was observed. No adverse effect was found for area in Bihar and Uttar Pradesh showed no response at all to early rainfall. In West Bengal, with its multi-cropped kharif season, rainfall in neighbouring OD and BH and remote $\mathrm{CH}$, EU all helped in operating of all types of irrigation and in Bihar, rainfall in neighbouring HW and more distant WU helped via rivers. Early rainfall within the state discouraged rice planting both in Punjab and Haryana but canals were also instrumental in doing this damage. Early rains in WU, also associated with canal irrigation, reduced rice area in Haryana but Bihar and EU rainfall helped in West Bengal. For yield, the impact of ESR was meagre, only limited to West Bengal's rainfall helping Assam, Bihar and West Bengal, Bihar's helping Assam, Bihar and Uttar Pradesh and WR's helping Punjab and Haryana. Rainfall in UT and JK helped and that in HP hurt yield in the Punjab-Haryana belt but the benefi- 
cial effect from UT came by tube well and other types of irrigation. In the east, Himalayan rainfall hardly had any impact.

MSR - Though planting starts earlier in many states now, the effect of rainfall in this season was seen to remain highly decisive for acreage as well as yield. In all cases, the rainfall in the growing state mattered for acreage and in most cases the role is favourable. No adverse effect of MSR was observed in Assam and Haryana. Rainfall in HC supplemented by canal irrigation prevented sowing in neighbouring Punjab but rainfall in HC as well as other regions all supported sowing in Haryana but only with power supply for irrigation or by recharging of ground water. Himalayan MSR (HP, UT, JK, EH, AR, AM and HW) was mostly found favourable for rice acreage. MSR in distant CA and neighbouring JH restrained planting in West Bengal. Effect of Himalayan rainfall differs among the states for yield but only adverse effects are identified of rainfall in AR, HP and UT but that in HW helped all three eastern states. Rainfall in WR helped yield in the Punjab-Haryana belt. Yield in Uttar Pradesh was served by rainfall across the state while canals brought water from rains in EM and BH. Similarly, rainfall in both HW and GW helped yield in West Bengal. Interaction with irrigation was limited. In Punjab and Haryana, canals and tube wells respectively helped in planting and canal and all irrigation respectively helped yield in Uttar Pradesh and Punjab. Rainfall in the entire Punjab-Haryana belt damaged yield in Haryana and Uttar Pradesh but helped yield in Punjab with irrigation.

LSR-As expect the influence is meagre and mostly damaging though both positive and negative effects of local or neighbouring rainfall are found in Assam, Punjab, Uttar Pradesh and West Bengal. No effect was found in Haryana and only adverse effect found in Bihar. Rainfall in JH hurt yield in Bihar and West Bengal and that in Himalayan regions were mostly adverse. The rainfall effects on yield came with no interaction with irrigation.

\subsection{Discussion}

During the sample period, rice area and yield responded to economic incentives in which public price policy had mattered gravely for controlling production. The weak role of the market in the absence of regulation or with dominant public support, is also exposed. Rainfall effect on both acreage and yield was far from simple as could be approximated by the local monsoon performance, a practice in popular dissemination. Spatial and temporal dimensions of rainfall effect were strong and local rainfall often had little consequence at least on acreage. Also, rainfall effect was in many cases adverse, suggesting inefficient redistribution of water across regions or time. In particular, shortfalls in utilization of water from Himalayan rainfall deserve attention.

Punjab and Haryana are observed to suffer from less than optimum water management not only of the local rainfall of Haryana but the outstanding adversity of directing water from Himachal Pradesh by the Bhankra-Nangal system. On the contrary, rainfall in JK has been highly useful, arguably an evidence of better management of Ravi water. Also, a favourable effect of rainfall in Rajasthan, which does not itself raise rice but shares water with rice producing states, is observed. Rainfall in HP, though not always adverse, carries a potential of being used more gainfully. These results may reflect the shortcomings of functioning of the Bhakra-Nangal system, of drainage problems, leakages from unlined canals, faulty slopes of canals and geological shape of the Haryana-Delhi area and landscape of Punjab regions. Indeed, a survey of the literature affirms the widespread threat of salinity and water-logging with high water table in parts of Haryana, and Punjab [39] attributable to wrong alignment of canals and the shapes of the terrains that make it hard to drain the water from heavy local rainfall. Water from incessant showers in Himachal Pradesh too are mostly drained from the mountains via many seasonal rivulets like Ghaggar and Tangri, that flood both the states [40] recurrently and remedial engineering has made the effect worse. High water heads stored in reservoir strigger sudden untimely water release to save dams. The existence of surface water projects backed by cheap electricity is associated with drastic shifts in cropping pattern from cotton to paddy in the kharif season and gradual fallowing and loss of crop yield in the waterlogged soil [41]. Though the Ganga and the Indus basins are separated at the surface, linkages in ground water cannot be ruled out but even at the surface, linking Satluj with Yamuna is in process ${ }^{10}$ despite dispute. Sind River which joins Yamuna could be linking northern India with Madhya Pradesh. Early rainfall has helped planting in Haryana, Punjab and West Bengal with power generation or recharge. The eastern plain states and the eastern Himalayas could be linked hydrologically by grid flow of electricity given the role of tube wells and other sources of irrigation and the role of other independent rivers is implicit.

\section{Concluding remarks}

It is clear that production is deeply related to geography and interventions that determine the quality of access to water, but while economic implications are relatively straight forward, the effect of rainfall is temporally and spatially varied and dispersed. The exercises divulged the complexity of water linkages that determine rice production by shaping its acreage and yield in varied locations. The same rainfall can have varying effects on area and yield in a year and on

\footnotetext{
${ }^{10}$ Sutlej River flows though the states of Himachal Pradesh, Punjab, Jammu and Kashmir and Haryana states. There is a proposed 214 kilometer Sutlej Yamuna link canal out of which $92 \mathrm{~km}$ canal has been already completed [42].
} 
the same in the following year. Thus, despite flooding in the current year, high rainfall can help production in future even negating a drought while a poor rainfall effect can spill over to the next years. The relations could be explained by not only river or canal hydrology or other known pathways of surface water supply but probably also by integration of ground water below the surface and sharing of hydroelectric power [2] from water stored in common reservoirs. Limited knowledge about nature, inadequate access to information on physical and spatial interconnectedness among weather and groundwater and paucity of trans-boundary data make the study and the explanations of the results at best a suggested approach though not all linkages could be covered.

Technological progress of farming, new techniques, inputs and seeds call for updating of information to contemporaneity instead of holding on to a static picture emerging from a particular sample. Dynamics also result from climate change. Evidently, every successive year's experience has been found to be an important addition to knowledge with the study conducted continually over years with updated data, encountering unprecedented rainfall events although the national average hides many of these truths. For example, in the year 2015-16, a year of monsoon failure at the all India level, HW and GW in the east stood out with surplus rainfall and the surplus in WR also contrasted the large deficits in the west. Subsequent years 2016-17, 2017-18 and 2018-19 are rated as normal for the country even though deficiency was widespread. Regions HW, GW, BH encountered big shortfalls in the east, leaving OD to enjoy a surplus just as PJ alone enjoyed surplus in the west in the normal year 2018-19. Regions in northeastern and western mountains showed heterogeneity. Post-monsoon rainfall was mostly poor.

Above all, water management has been undergoing developments and is especially in a significant transition in the current scenario. To increase irrigation potential, mitigate floods, droughts and regional imbalances in water availability a way identified is the Inter Basin Water Transfer (IBWT) from surplus rivers to deficit areas, the progress of which would make results of the exercise highly sensitive to the sample chosen. Linking Ken and Betwa, Yamuna and Satluj, cross-boundary rivers Manas, Sankosh, Tista and Ganga ${ }^{11}$ in the north-east and the contentious proposal of joining surplus rivers Brahmaputra and Ganga and their northern tributaries with Mahanadi, Godavari and West flowing rivers from Western Ghats would create new pathways for water to flow provoking the model to possibly identify rainfall in remote and yet unconnected sites as important for rice production. The model over time will tend to trail changes like greater use of aquifer knowledge and conjunctivity of irrigation types, realization of the hydro-power project proposals of the northeast, strengthening of power grids, resolution of water management issues between states and greater international cooperation.

\section{Acknowledgement}

Authors thank Ms. Yashika Rani for data operation and acknowledge the funds provided by Government of India, Ministry of Agriculture \& Farmers Welfare for FASAL project for which the data is collected and analysed.

\section{References}

[1] NITI AAYOG. (2015). Raising Agricultural Productivity and Making Farming Remunerative for Farmers. An occasional paper, Government of India. https://niti.gov.in/sites/default/files/2019-08/Raising\%20Agricultural\%20Productivity\% 20and\%20Making\%20Farming\%20Remunerative\%20for\%20Farmers.pdf.

[2] Srinivasan Shweta, Nazar Kholod, Vaibhav Chaturvedi, Probal Pratap Ghosh, Ritu Mathur, Leon Clarke, Meredydd Evans, Mohamad Hejazi, Amit Kanudia, Poonam Nagar Koti, Bo Liu, Kirit S. Parikh, Mohd. Sahil Ali, Kabir Sharma. (2017). Water for electricity in India: A multi-model study of future challenges and linkages to climate change mitigation. Applied Energy, https://www.osti.gov/pages/servlets/purl/1364388.

[3] Joshi, P. K., Ashok Gulati, Pratap S. Birthal, Laxmi Tewari. (2004). Agriculture Diversification in South Asia Patterns, Determinants and Policy Implications. Economic and Political Weekly June 12.

[4] NITI AAYOG. (2016). Evaluation Study on Efficacy of Minimum Support Prices (MSP) on Farmers. DMEO Report No. 231, Government of India. https://niti.gov.in/writereaddata/files/writereaddata/files/document_publication/MSP-report.pdf.

[5] Narayanamoorthy, A. (2018). Financial performance of India's irrigation sector: a historical analysis. International Journal of Water Resources Development, 34:1, 116-131, DOI: 10.1080/07900627.2017.1298998.

[6] Ministry of Water Resource (MoWR) (Website). National Water Policy 2012. Government of India. http://jalshakti-dowr.gov.in/sites/default/files/NWP2012Eng6495132651_1.pdf.

[7] Agarwal, A. and Narayan S. (1991). State of India’s Environment: Floods. Centre for Science and Environment, N. Delhi.

[8] Nandargi, S. S. and A. Shelar. (2018). Rainfall and Flood Studies of the Ganga River Basin in India. Annals of Geographical Studies Volume 1, Issue 1, 2018, PP. 34-50, Sryahwa publications.

\footnotetext{
${ }^{11}$ Essentially the Manas-Sankosh-Teesta-Ganga link project proposes linking Brahmaputra of north-east with the Ganga basin. The canal envisages diversion of the surplus waters of Manas and Sankosh rivers, with supplementation from the intermediate major streams, for the benefit of augmenting the flows of Ganga at Farakka (in West Bengal) as also irrigation and power generation.
} 
[9] Rosul, Golam. (2014). Food, water, and energy security in South Asia: A nexus perspective from the Hindu Kush Himalayan region. Environmental Science \& Policy Volume 39, May, Elsevier, Pages 35-48.

[10] Nepal, Santosh, Avash Pandey, Arun B. Shrestha, and Mukherji, Aditi. (2018). Revisiting Key Questions Regarding Upstream-Downstream Linkages of Land and Water Management in the Hindu Kush Himalaya (HKH) Region. Working Paper 21, Himalayan Adaptation, Water and Resilience Research (HI-AWARE), Kathmandu, Nepal, November.

[11] Hill, Douglas. (2017). The Discursive Politics of Water Management in India: Desecuritising Himalayan River Basins. South Asia: Journal of South Asian Studies. 40. 1-17.

[12] United Nations (UN). (2015). The Millennium Development Goals Report 2015. https://www.un.org/millenniumgoals/2015_ MDG_Report/pdf/MDG\%202015\%20rev\%20(July\%201).pdf.

[13] Velde, M. van der and L. Nisini. (2019). Performance of the MARS-crop yield forecasting system for the European Union: Assessing accuracy, in-season, and year-to-year improvements from 1993 to 2015. Elsevier, Agricultural Systems 168, 203-212.

[14] Diepen, C. A. Van, I. Supit, Catalin Lazar, Erik van der Goot. (2004). Methodology of the MARS crop yield forecasting system. Vol. 2 agrometeorological data collection, processing and analysis. European Commission Joint Research Centre.

[15] Fritz, Steffen. et al. (2019). A comparison of global agricultural monitoring systems and current gaps. Elsevier, Agricultural Systems 168, 258-272.

[16] Vogel, Frederic A. and Gerald A. Bange (1999). Understanding USDA Crop Forecasts. United States Department of Agriculture, National Agricultural Statistics Service, Office of the Chief Economist, World Agricultural Outlook Board, Publication No. 1554, March, Washington, D.C.

[17] Wang, J., Zhang, Z. Su, B., and Zhang L. (2012). A case research on economic spatial distribution and differential of agriculture in China. Agricultural science, 3(8), 996-1006.

[18] Singh, V. P., Nayan Sharma, C. Shekhar P. Ojha. (2004). The Brahmaputra Basin Water Resources. Publisher: Springer Science \& Business Media.

[19] Sreevatsan, Ajai. (2019). Proposal for interlinking of rivers is erroneous: Mihir Shah. Livmint, $4^{\text {th }}$ July. https://www.livemint.com/news/india/proposal-for-interlinking-of-rivers-is-erroneous-mihir-shah-1562178918712.html.

[20] Suhag, Roopal. (2016). Overview of Ground Water in India. PRS, https://ideas.repec.org/p/ess/wpaper/id9504.html.

[21] Sharma, Bharat, Upali Amarasinghe, Cai Xueliang, Devaraj de Condappa, Tushaar Shah, Aditi Mukherji, Luna Bharati, G. Ambilia, Asad Qureshif, Dhruba Pante, Stefanos Xenariosa, R. Singhg, and Vladimir Smakhtin. (2010). The Indus and the Ganges: river basins under extreme pressure. Water International Vol. 35, No. 5, September 2010, 493-521, Routledge Taylor and Francis Group.

[22] Shaheen, Farhet, \& Shah, Farhed A. (2017). "Climate Change, Economic Growth, and Cooperative Management of Indus River Basin,” 2017 Annual Meeting, July 30-August 1, Chicago, Illinois 258350, Agricultural and Applied Economics Association.

[23] Mukherji, Aditi. (2007). The energy-irrigation nexus and its impact on groundwater markets in eastern Indo-Gangetic basin: Evidence from West Bengal, India. Energy Policy 35(12):6413-6430. December.

[24] Ghosh, Nilanjan. (2016). The New Pathway: Is Sub-Regional BBIN a Role Model for Asian Connectivity?. Publisher: Observer Research Foundation.

[25] Shagun, Kapil. (2019). Dams were built to control floods; they are now triggers. Down to Earth, Wednesday 18 September.

[26] India Water Portal (Website). Large Dams, barrages, reservoirs and canals. https://www.indiawaterportal.org/topics/ large-dams-barrages-reservoirs-and-canals

[27] World Commission. (2000). Dams and Developments: A new framework for decision making. The report of the World Commission on Dams. https://www.internationalrivers.org/sites/default/files/attached-files/world_commission_on_dams _final_report.pdf.

[28] Moran Tara, Janny Choy, and Carolina Sanchez. (2014). The Hidden Costs of Groundwater Overdraft. Understanding California Groundwater, Water in the West. https://waterinthewest.stanford.edu/groundwater/overdraft/.

[29] Gosain, Ashvani, \& Rao, Sandhya. (2007). Impact assessment of climate change on water resources of two river systems in India. Jalvigyan Sameeksha. 22.

[30] Food and Agriculture Organisation (FAO). (2008). Modernization Strategy for Irrigation Management Uttar Pradesh-India Main Ganga Canal System. Uttar Pradesh Irrigation Department. http://www.fao.org/3/a-bc050e.pdf\%20p.

[31] Dhawan, B. D. (1995). Magnitude of Groundwater Exploitation. Economic and Political Weekly, Vol. 30, Issue No. 14, 08 April.

[32] Ramaswamy R. Iyer. (2015). Living Rivers, Dying Rivers. Oxford University Press.

[33] Central Ground Water Board (CGWB). (2018). Ground Water Quality in Shallow Aquifers of India. Ministry of Water Resources RD \& GR Government of India. 
[34] Ghosh, Nilabja, Amarnath, Tripathi, M. Rajeshwor, R. Verma, and S. K. Shankar. (2016). Problems of Water and Food Insecurity in the Indian part of the Kosi River Basin: A Study on Agriculture. Institute of Economic Growth, Report submitted to International Centre for Integrated Mountain Development (ICIMOD) Kathmandu, Nepal.

[35] Wahid, S., Kilroy, G., Shrestha, A., Bajracharya, S., \& Hunzai, Kiran. (2017). Opportunities and Challenges in the Trans-boundary Koshi River Basin. 10.1007/978-981-10-1472-7_18.

[36] Nepal, Santosh, Wolfgang-Albert Flügel, Arun Bhakta Shrestha. (2016). Upstream-downstream linkages of hydrological processes in the Himalayan region. Ecological Processes volume 3, Article number: 19.

[37] Nerlove M. (1958). The Dynamics of Supply: Estimation of Farm supply Response to Price, Johns Hopkins University Press, Baltimore.

[38] Sheffrin, Steven M. (1983). Rational Expectations. Cambridge University Press, Cambridge.

[39] Indo-Dutch Network Project (IDNP). (2002). Recommendations on Waterlogging and Salinity Control Based on Pilot Area Drainage Research. CSSRI, Karnal and Alterra-ILRI, Wageningen.

[40] Sarkar, Soumya. (2019). Extreme rainfall and bad infrastructure lead to extreme Indian floods. August 23, the third pole.net Understanding Asia's water crisis. https://www.thethirdpole.net/2019/08/23/extreme-rainfall-and-bad-infrastructurelead-to-extreme-indian-floods/.

[41] ASSOCHAM. (2017). Accelerating hydropower development in India for sustainable energy security. https://www.pwc.in/assets/pdfs/publications/2017/accelerating-hydropower-development-in-india-for-sustainable-energy-securi ty.pdf.

[42] Ministry of Jal Shakti (MoJS) (Website). Sutlej-Yamuna Link Canal. http://mowr.gov.in/sutlej-yamuna-link-canal. 